\title{
Novos métodos de simulação em ácidos nucleicos
}

Paulo Augusto Netz ${ }^{1}$ (PQ) netz@iq.ufrgs.br

${ }^{1}$ Universidade Federal do Rio Grande do Sul, Porto Alegre, RS, Brasil

Palavras-chave: ácidos nucleicos, simulação multiescala, PMF, SMD, Energia livre.

Apesar da inegável importância dos ácidos nucleicos (DNA e RNA) para a genética, bioquímica, biologia molecular e farmacologia, eles tem sido muito menos estudados que as proteínas, mediante métodos computacionais. $\mathrm{O}$ grande tamanho das moléculas de DNA, a variabilidade estrutural e conformacional do RNA e as interações peculiares tornam a simulação dos ácidos nucleicos um desafio que recém estamos começando a enfrentar. Dentre os aspectos que precisam ser considerados em simulações de dinâmica molecular estão a necessidade da escolha adequada de campo de forças e da descrição das interações eletrostáticas, bem como do preparo da estrutura inicial, contemplando a distribuição de íons e solvatação. Considerando ainda a interação entre diversas escalas temporais e espaciais, o estudo computacional dos ácidos nucleicos demanda, para além das simulações clássicas atomísticas de equilíbrio, uma ampla gama de métodos, como simulações multi-escala[1], que combinam a representação simultânea atomística e coarse-grained, bem como métodos de simulação de não equilíbrio, os quais fornecem a possibilidade de se investigar a dinâmica de ácidos nucleicos de modo bastante próximo aos procedimentos experimentais, como microscopia de força atômica.

[1]Netz, Paulo Augusto; Potestio, Raffaello; Kremer, Kurt Adaptive resolution simulation of oligonucleotides Journal of Chemical Physics 145, 234101 (2016) 